\title{
Model Pembelajaran Kooperatif STAD untuk Meningkatkan Hasil Belajar Materi Dinamika Penduduk di SMP Pangudi Luhur Bintang Laut Surakarta
}

\author{
Stephanus Darminto 4 \\ akreditasitp20@gmail.com
}

Abstract: This type of research is classroom action research. The purpose of this study was to improve Social Studies learning outcomes in the material of Population Dynamics of Grade VIII D students. The research subject was 39 students Class VIII D of Pangudi Luhur Bintang Laut Surakarta Junior High School. Data collection techniques and tools from learning outcomes use pre-test and post-test learning outcomes. Data analysis uses descriptive qualitative and reflective techniques. The conclusion of this study is the classical completeness of class VIII D students in semester 1 of social studies subjects is 50\% can be overcome by applying the type of cooperative learning methods. This research was conducted in two cycles for students of class VIII D semester 1 of Pangudi Luhur Bintang Laut Surakarta Junior High School. Each cycle consists of four components of action research, namely planning, action, observation and reflection. The results also showed an increase in learning outcomes, namely the first cycle with the acquisition of an average grade of 85.85 with $75 \%$ classical completeness and the second cycle with an average acquisition of 90.82 with $95 \%$ classical completeness. The results obtained indicate that the application of the STAD type cooperative learning model can improve the learning outcomes of students of class VIII D of Pangudi Luhur Bintang Laut Surakarta Junior High School.

Keywords: Learning Outcomes, Cooperative Learning Model, STAD

\footnotetext{
${ }^{4}$ SMP Pangudi Luhur Bintang Laut Surakarta
} 


\section{PENDAHULUAN}

$P^{s}$ endidikan adalah usaha sadar dan terencana untuk mewujudkan suasana belajar dan proses pembelajaran agar peserta didik secara aktif mengembangkan potensi dirinya untuk memiliki kekuatan spiritual keagamaan, pengembangan diri, kepribadian, akhlak mulia, serta ketrampilan yang dimiliki dirinya, masyarakat, bangsa dan negara (Undang-Undang Nomor 20 Tahun 2003 pasal 1, butir 1 ). Dalam Kurikulum 2004 yang disempurnakan juga diharapkan bahwa proses pembelajaran harus mampu menciptakan suasana yang aktif, kreatif dan menyenangkan sehingga siswa mampu mengembangkan diri sesuai dengan lingkungannya. Namun demikian sampai saat ini dunia pendidikan kita masih didominasi oleh pandangan bahwa pengetahuan merupakan seperangkat fakta yang harus dihafal. Guru adalah ujung tombak dalam pembelajaran untuk dapat meningkatkan kualitas pembelajaran. Kelas sebagian besar masih berfokus pada guru sebagai sumber pengetahuan yang utama, dan ceramah menjadi pilihan utama dalam strategi pembelajaran.

Itulah kenyataan yang dihadapi oleh sebagian besar guru IPS. Materi pelajarannya yang kompleks, sering dianggap sebagai pelajaran yang mudah tapi susah, bersifat hafalan dan membosankan, sehingga menyebabkan rendahnya perhatian dan partisipasi siswa dalam kegiatan pembelajaran. Rendahnya perhatian siswa pada mata pelajaran IPS, ditambah dengan strategi pembelajaran yang kurang menarik menyebabkan rendahnya prestasi siswa. Kondisi yang demikian terjadi pula di SMP Pangudi Luhur Bintang laut Surakarta. Hasil belajar siswa kelas VIII D terhadap mata pelajaran IPS selama ini masih rendah karena nilai ulangan mereka tidak sampai $75 \%$ yang bisa mencapai nilai KKM. Hal itu menandakan bahwa pembelajaran IPS kurang menarik, karena guru masih menggunakan menggunakan model pembelajaran yang kurang merangsang siswa untuk belajar lebih giat, dan proses pembelajaran masih menekankan pada aspek pengetahuan saja, belum menyentuh pada sikap dan kreatifitas siswa, karena guru kurang melibatkan siswa agar aktif dalam proses pembelajaran.

Rendahnya hasil belajar IPS pada siswa kelas VIII D SMP Pangudi Luhur Bintang Laut Surakarta dapat dilihat dari rendahnya nilai ulangan siswa untuk mata pelajaran IPS. Hasil ulangan harian siswa sebelum diadakan tindakan hanya $60 \%$ siswa yang dapat mencapai $\mathrm{KKM}$, atau siswa yang memiliki nilai diatas 75 masih jauh dari $75 \%$, sehingga dapat dikatakan bahwa kegiatan pembelajaran tidak tuntas. Kegiatan ulangan remidialpun seringkali tidak dapat membantu memperbaiki dan menaikkan nilai mereka. Selama ini dalam kegiatan pembelajaran guru masih menggunakan metode ceramah yang diterapkan secara murni, sehingga siswa merasa tidak pernah dilibatkan dalam kegiatan pembelajaran. Siswa seolah-olah hanya diharuskan untuk menghafal fakta-fakta, sehingga siswa merasa bosan dan kurang berminat terhadap kegiatan pembelajaran. Keadaan yang demikian ternyata menjadi salah satu fakta yang berpengaruh terhadap rendahnya hasil belajar siswa.

Piaget (dalam Paul Suparno 2005), menyatakan bahwa pengetahuan yang dimiliki seseorang dibentuk sendiri oleh orang tersebut melalui kegiatan atau keaktifan orang itu dalam berhadapan dengan tantangan, rangsangan atau persoalan, kemudian mengasimilasi dengan menghubungkan dengan pengertian yang dimiliki sebelumnya. Sedangkan menurut Ali \& Asrori (2008), siswa belajar dengan cara mencocokkan informasi baru yang telah mereka peroleh bersama-sama dengan apa yang telah mereka ketahui. Siswa akan dapat belajar dengan baik jika mereka mampu mengaktifkan konstruk pemahaman mereka sendiri. Sedangkan menurut Slameto (2003) menyatakan bahwa belajar adalah suatu proses usaha yang dilakukan seseorang untuk memperoleh suatu perubahan tingkah laku yang baru secara keseluruhan, sebagai hasil pengalamannya sendiri dalam interaksi dengan lingkungannya. Belajar adalah suatu aktivitas mental/psikis yang berlangsung dalam interaksi aktif dengan lingkungan yang menghasilkan perubahan-perubahan dalam pengetahuan-pemahaman, ketrampilan dan nilai sikap. Belajar merupakan proses aktif pelajar mengkontruksi entah dari teks, dialog, pengalaman fisik dan lainlain. Belajar juga merupakan proses membuat penalaran atas apa yang dipelajari dengan cara mencari makna, membandingkan dengan apa yang telah ia ketahui dengan apa yang ia perhatikan dalam 
pengalaman yang baru. Pengetahuan tidak dapat ditransfer dari seorang guru yang dianggap tahu kepada siswa.

Proses tersebut bercirikan antara lain: 1) Belajar berarti membentuk makna. Makna diciptakan sendiri oleh siswa dari apa yang mereka lihat, mereka dengar, mereka rasakan dan mereka alami. Proses konstruksi dipengaruhi oleh pengertian yang telah ia punyai. 2) Belajar merupakan proses mengkontruksi arti yang berlangsung secara terus menerus setiap kali berhadapan dengan fenomena atau persoalan yang baru. Proses kontruksi itu berlangsung, baik secara kuat atau lemah. 3) Belajar bukanlah kegiatan mengumpulkan fakta, melainkan lebih ke suatu pengembangan pemikiran dengan membuat pengertian baru. 4) Proses belajar yang sebenarnya terjadi pada waktu skema seseorang dalam keraguan yang merangsang pemikiran lebih lanjut. Situasi ketidakseimbangan (disequilibrium) adalah situasi yang baik untuk memacu belajar. 5) Pengalaman belajar dengan dunia fisik dan lingkungan dapat mempengaruhi hasil belajar.6) Kemampuan awal siswa, tujuan pembelajaran, dan motivasi belajar sangat berpengaruh terhadap hasil belajar (Sudjana, 2007).

Hasil belajar seseorang akan dipengaruhi oleh dua hal yaitu kondisi internal dan kondisi eksternal. Kondisi internal meliputi usia, minat, profesi, kesehatan, motivasi, prestasi, kemampuan, status sosial dan ekonomi atau kemampuan berbahasa asing. Sedang kondisi eksternal adalah rangsangan yang bersumber dari luar yang dapat menyebabkan terjadinya proses belajar mengajar. Kondisi eksternal dalam proses belajar mengajar dipengaruhi antara lain oleh guru dan metode mengajar. Dalam hal ini bagaimana guru merancang dan menyediakan kondisi yang khusus agar siswa berhasil dalam belajarnya. Kegagalan seseorang dalam belajar tidak semata-mata disebabkan oleh kemampuannya tetapi antara lain adanya gangguan dari informasi lain yang menghambat atau mengingat kembali apa yang pernah telah dipelajarinya. Hasil belajar yang dicapai siswa melalui proses belajar-mengajar yang optimal cenderung menunjukkan hasil yang berciri sebagai berikut: 1) Kepuasan dan kebanggan yang dapat menumbuhkan motivasi belajar intrinsik pada diri siswa. Motivasi intrinsik adalah semangat juang untuk belajar yang tumbuh dalam diri siswa itu sendiri. 2) Menambah keyakinan akan kemampuan dirinya. Artinya ia tahu akan kemampuan dirinya dan percaya bahwa ia punya potensi yang tidak kalah dari orang lain apabila ia berusaha sebagaimana seharusnya. 3) Hasil belajar yang dicapainya bermakna bagi dirinya seperti tahan lama diingatnya, membentuk perilakunya, bermanfaat untuk mempelajari aspek lain, dapat digunakan sebagai alat untuk memperoleh informasi dan pengetahuan lainnya, kemauan dan kemampuan untuk belajar sendiri dan mengembangkan kreatifitasnya. 4) Hasil belajar diperoleh siswa secara menyeluruh, yakni mencakup ranah kognitif, afektif dan psikomotorik. 5) Kemampuan siswa untuk mengontrol atau menilai dan mengendalikan dirinya terutama dalam menilai hasil yang dicapainya, mengendalikan proses dan usaha belajarnya (Sudjana, 2007; Hamalik, 2005)..

Ilmu pengetahuan sosial, yang sering disingkat dengan IPS adalah ilmu pengetahuan yang mengkaji berbagai disiplin ilmu sosial dan humaniora serta kegiatan dasar manusia yang dikemas secara ilmiah dalam rangka memberi wawasan dan pemahaman yang mendalam kepada peserta didik, khususnya di tingkat dasar dan menengah. Luasnya kajian IPS ini mencakup berbagai kehidupan sosial, ekonomi, psikologi, budaya, sejarah maupun politik, semuanya dipelajari dalam ilmu sosial ini. IImu Pengetahuan Sosial merupakan salah satu mata pelajaran pokok pada jenjang pendidikan dasar. Pembelajaran IPS sangatlah penting karena materi-materi yang didapatkan siswa di sekolah dapat dikembangkan menjadi sesuatu yang lebih bemakna ketika siswa berada di lingkungan masyarakat, baik di masa sekarang ataupun di masa yang akan datang.

Dengan demikian, sehubungan dengan pengertian hasil belajar dan pembelajaran IPS yang telah dijabarkan di atas dapat disimpulkan bahwa hasil belajar IPS merupakan hasil optimal siswa baik dalam aspek kognitif, afektif, ataupun psikomotorik yang diperoleh siswa setelah memperlajari IPS dengan jalan mencari berbagai informasi yang dibutuhkan baik berupa perubahan tingkah laku, pengetahuan, maupun keterampilan sehingga siswa tersebut mampu mencapai hasil maksimal belajarnya sekaligus 
memecahkan masalah yang berkaitan dengan masalah sosial dan menerapkannya dalam kehidupan masyarakat.

Penyebab mengapa prestasi belajar siswa rendah pada setiap ulangan harian dapat diduga antara lain karena siswa kurang memahami konsep pengajaran IPS. Siswa kurang termotivasi menyelesaikan tugas rumah (PR), minat baca siswa rendah, dan tidak mau bertanya pada saat proses pembelajaran. Guru masih menggunakan metode ceramah sehingga kurang melibatkan siswa untuk aktif dalam pelajaran, Akibatnya materi pelajaran menjadi kurang menarik.

Kegiatan belajar mengajar siswa dipengaruhi oleh guru, salah satu hal yang mempengaruhi adalah model pembelajaran yang dipilih oleh guru. Pendekatan pembelajaran yang dipilih guru akan membentuk perilaku dan sikap siswa. Model pembelajaran yang bernuansa kompetisi akan menyebabkan siswa cenderung bekerja keras dan membentuk pribadi yang kurang bisa kerjasama. Salah satu model pembelajaran yang bisa menumbuhkan sikap kerjasama adalah model pembelajaran kooperatif. Pembelajaran kooperatif (cooperative learning) adalah mencakup kelompok kecil siswa yang bekerjasama sebagai sebuah tim menyelesaikan suatu masalah, menyelesaikan suatu tugas atau mengerjakan sesuatu untuk mencapai tujuan bersama lainnya.

Dari berbagai permasalahan di atas, ada satu masalah utama yang perlu mendapat perhatian, yaitu meningkatkan hasil belajar siswa pada pelajaran IPS. Upaya yang diperkirakan dapat meningkatkan hasil belajar siswa pada pelajaran IPS ialah dengan menggunakan model pembelajaran kooperatif STAD. Pada model pembelajaran kooperatif STAD ini menekankan pada aktivitas dan interaksi diantara siswa untuk saling memotivasi dan saling membantu dalam menguasai materi pelajaran guna mencapai prestasi yang maksimal (Hutabalian \& Gunansyah, 2013).

Pembelajaran kooperatif merupakan metode pembelajaran dengan menggunakan sistem pengelompokan atau tim kecil, yaitu antara empat sampai enam orang yang mempunyai latar belakan kemampuan akademik, jenis kelamin, ras, atau suku yang berbeda (heterogen). Sistem penilaian dilakukan terhadap kelompok. Setiap kelompok akan memperoleh penghargaan (reward), jika kelompok mampu menunjukkan prestasi yang dipersyaratkan. Sehingga anggota kelompok akan mempunyai ketergantungan positif. Ketergantungan semacam itulah yang selanjutnya akan memunculkan tanggung jawab individu terhadap kelompok dan ketrampilan interpersonal dari setiap anggota kelompok (Rocmatin \& Gunansyah, 2014). Setiap individu akan memiliki kesempatan yang sama untuk memberikan kontribusi demi keberhasilan kelompok.

Model pembelajaran kelompok adalah rangkaian kegiatan belajar yang dilakukan oleh siswa dalam kelompok-kelompok tertentu untuk mencapai tujuan pembelajaran yang telah dirumuskan. Ada empat unsur penting dalam pembelajaran kooperatif, yaitu (1) adanya peserta dalam kelompok; (2) adanya aturan kelompok; (3) adanya upaya belajar setiap anggota kelompok; (4) adanya tujuan yang harus dicapai (Purwati, Akhyar, \& Fadhilah, 2017).

Belajar dalam kelompok kecil yeng terdiri dari siswa yang heterogen dalam kemampuan belajarnya akan menjadi transfer pengetahuan dari siswa yang berkemampuan tinggi ke siswa yang berkemampuan rendah, sehingga akan memotivasi ke siswa yang rendah berkemampuannya agar dapat mengimbangi temannya yang kemampuan belajarnya lebih tinggi. Sebaliknya siswa yang kemampuan belajarnya tinggi akan semakin tinggi kemampuan belajarnya dengan dia menerangkan kepada temannya. Belajar kelompok secara sosial menjadikan siswa belajar bekerjasama, belajar menghargai antar teman, dan belajar menjadi tutor. Dalam kelompok kecil yang terdiri dari siswa laki-laki dan perempuan akan terbantu oleh siswa laki-laki atau perempuan yang mempunyai daya pandang yang lebih baik, sehingga kesulitan belajar yang dialami siswa laki-laki maupun perempuan akan teratasi.

Dengan menggunakan model pembelajaran ini diharapkan akan dapat menumbuhkan perhatian siswa terhadap mata pelajaran IPS, karena siswa akan aktif mencari jawaban atas pertanyaanpertanyaan yang harus diselesaikan. Partisipasi aktif siswa dalam proses pembelajaran akan dapat 
meningkatkan hasil belajarnya. Tujuan yang ingin dicapai dalam penelitian tindakan kelas ini adalah meningkatkan hasil belajar IPS melalui penggunaan model pembelajaran kooperatif STAD pada siswa kelas VIII D SMP Pangudi Luhur Bintang Laut Surakarta.

\section{METODE PENELITIAN}

Penelitian dilakukan di SMP Pangudi Luhur Bintang Laut Surakarta kelas VIII D, pada semester 1 tahun pembelajaran 2017-2018 pada bulan Agustus-September 2017. Penelitian ini dilakukan di unit kerja peneliti yaitu SMP Pangudi Luhur Bintang Laut Surakarta kelas VIII D. Rombel kelas VIII SMP PL Bintang Laut terdiri dari 8 kelas yaitu dari kelas VIII A sampai dengan VIII H. Peneliti memilih kelas VIII D karena untuk kelas VIII peniliti mengajar kelas VIII A, VIII B, VIII C, VIII D, dan diantara empat kelas tersebut kelas VIII D prestasinya paling rendah. Subjek penelitian yaitu siswa kelas VIII yang berjumlah 39 siswa. Dari 39 siswa tersebut terdiri dari 19 siswa laki-laki dan 20 siswa perempuan. Objek penelitian ini adalah peningkatan hasil belajar IPS pada materi Dinamika Penduduk dengan penerapan Model Belajar STAD.

Sumber data penelitian adalah hasil tes meliputi 1) data hasil belajar materi Permasalahan Kependudukan di Indonesia, Dampak, dan Upaya Mengatasinya sebagai kondisi awal 2) data hasil belajar pre-tes dan post-tes tentang Macam Pertumbuhan Penduduk dan Faktor yang Mempengaruhinya 3) data hasil belajar pre-tes dan post-tes Kondis Penduduk Indonesia Berdasarkan Bentuk Piramida Penduduknya 4) serta pengamatan pada saat proses belajar di kelas dan pengamatan dari teman sejawat.

Pengumpulan data dengan menggunakan pre-tes dan post-tes pada setiap siklus penelitian. Sedangkan laporan pengamatan oleh pengamat/observer dilaksanakan pada setiap pertemuan pembelajaran dan diberikan peneliti setelah akhir pertemuan pembelajaran. Hal ini dilakukan sampai dua siklus. Teknik analisa data yang digunakan adalah diskriptif kualitatif dari data, reflektif dan laporan dari pengamat/observer selama 2 siklus. Instrumen penelitian berupa soal pre-tes dan soal post-tes yang disesuaikan dengan indikator. Dari pre-tes dan post-tes hasil belajar tersebut kemuadian dibandingkan. Nilai belajar pada pre-tes merupakan hasil belajar sebelum mendapatkan perlakuan dengan model pembelajaran STAD. Sedangkan hasil belajar pada post-tes merupakan nilai setelah mendapatkan perlakuan dengan model pembelajaran STAD.

Hipotesis dari penggunaan model kooperatif STAD diharapkan dapat meningkatkan hasil belajar siswa. Pencapaian pada siklus I diharapkan yang memperoleh nilai ketuntasan secara klasikal sebesar $75 \%$ dan pada siklus ke II diharapkan memperoleh ketuntasan klasikal $80 \%$ atau lebih.

Prosedur penelitian tindakan kelas ini terdiri atas dua siklus. Masing-masing siklus menggunakan waktu pembelajaran $2 \times 40$ menit. Tiap siklus terdiri atas kegiatan perencanaan, tindakan, observasi dan refleksi. Pengambilan data dari penelitian ini dilakukan dengan teknik observasi, dan penilaian hasil tes. Penilaian tes dilakukan dua kali penelitian untuk kemampuan mengerti dan memahami dinamika penduduk pada siklus I dan siklus II. Kegiatan observasi dilakukan selama proses pembelajaran berlangsung. Pelaksanaan prosedur penilitian yang akan dilakukan oleh peneliti adalah sebagai berikut:

1. Diskripsi siklus I.

a. Tahap perencanaan tindakan.

Dalam perencanaan tindakan pada siklus ini, kegiatan yang dilakukan adalah: 1) Peneliti menyusun silabus yang berkaitan dengan materi dinamika penduduk. 2). Peneliti merancang skenario pembelajaran. 3) Merancang alat pengumpul data yang berupa tes dan digunakan untuk mengetahui pemahaman kemampuan siswa yang berkaitan dengan materi dinamika penduduk.

b. Tahap pelaksanaan tindakan 
Memberikan penjelasan secara umum tentang materi yang diajarkan dengan menggunakan media power point kemudian membagikan lembar kerja yang akan dikerjakan dalam kelompok. Mengamati dan mencatat siswa yang berpartisi aktif dalam pembelajaran. Menganalisa hasil tes yang diberikan setelah siswa mengikuti pembelajaran. Peniliti mengajar sesuai dengan skenario pembelajaran yang telah dirancang dan mengamati, mencatat kegiatan - kegiatan yang dilakukan oleh siswa. Evaluasi diberikan oleh peneliti dalam bentuk post-tes dinamika penduduk.

C. Tahap observasi tindakan.

Peneliti mengamati dan mencatat semua kejadian yang terjadi pada saat siswa mengikuti pengajaran dan menanyakan pada siswa kesulitan - kesulitan yang dihadapinya.

d. Tahap refleksi.

Peneliti menganalisa hasil pekerjaan siswa dan hasil observasi yang dilakukan pada siswa guna menentukan langkah berikutnya.

2. Diskripsi siklus II.

a. Tahap perencanaan tindakan.

Dalam perencanaan tindakan pada siklus ini, kegiatan yang dilakukan adalah: 1) Peneliti menyusun silabus yang berkaitan dengan materi dinamika penduduk. 2). Peneliti merancang skenario pembelajaran. 3) Merancang alat pengumpul data yang berupa tes dan digunakan untuk mengetahui pemahaman kemampuan siswa yang berkaitan dengan materi dinamika penduduk.

b. Tahap pelaksanaan tindakan

Pada siswa diberikan pre-tes. Kemudian dilanjutkan memberikan penjelasan secara umum tentang materi yang diajarkan dengan menggunakan media power point kemudian membagikan lembar kerja yang akan dikerjakan dalam kelompok. Mengamati dan mencatat siswa yang berpartisi aktif dalam pembelajaran. Menganalisa hasil tes yang diberikan setelah siswa mengikuti pembelajaran. Peniliti mengajar sesuai dengan skenario pembelajaran yang telah dirancang dan mengamati, mencatat kegiatan - kegiatan yang dilakukan oleh siswa. Evaluasi diberikan oleh peneliti dalam bentuk post-tes dinamika penduduk.

c. Tahap observasi tindakan.

Peneliti mengamati dan mencatat semua kejadian yang terjadi pada saat siswa mengikuti pengajaran dan menanyakan pada siswa kesulitan - kesulitan yang dihadapinya.

d. Tahap refleksi.

Peneliti menganalisa hasil pekerjaan siswa dan hasil observasi yang dilakukan pada siswa untuk pembuatan laporan penelitian.

\section{HASIL DAN PEMBAHASAN}

\section{A. Diskripsi Kondisi Awal}

Berdasarkan pengalaman mengajar peneliti sebagai guru di SMP Pangudi Luhur Bintang Laut Surakarta pada ulangan materi Dinamika Penduduk, siswa sering mendapat hasil belajar di bawah KKM. Kondisi inilah yang menarik peneliti untuk melakukan penelitian. Siswa pada saat pembelajaran terkadang juga kurang terlibat secara aktif. Kemampuan siswa untuk menangkap penjelasan guru menjadi kurang karena siswa tidak terlibat secara aktif dalam proses belajar mengajar. 
Model pembelajaran yang dipakai guru, seharusnya perlu bervariasi sehingga tidak terjadi kebosanan dalam pembelajaran. Pada materi Dinamika Penduduk peniliti menggunakan metode ceramah, ternyata hasil belajarnya masih di bawah KKM. Kemampuan memahami dan mengerti tentang dinamika penduduk siswa kelas VIII D SMP Pangudi Luhur Bintang Laut Surakarta sangat rendah. Kondisi ini sangat dipengaruhi situasi siswa yang kurang aktif. Seringkali siswa tidak mau atau tidak berani mengajukan pertanyaan pada guru, padahal siswa belum mengerti penjelasan guru.

Pada ulangan harian pertama sebelum diadakan siklus, siswa yang tuntas (mencapai KKM) atau memiliki nilai 75 keatas sebanyak 20 orang atau sebesar $55,6 \%$. Siswa yang tidak tuntas atau dengan nilai kurang dari 60 sebanyak 16 orang atau sebesar $44,4 \%$, dengan nilai rata-rata kelas 55,8. Dari gambaran keadaan diatas dapat disimpulkan bahwa ketuntasan belajar kelas VIII D secara klasikal belum tuntas, karena baru mencapai $55,6 \%$ atau kurang dari $75 \%$ siswa yang tuntas atau mendapatkan nilai minimal 60 , nilai yang diperoleh siswapun masih berada pada nilai dengan tingkat sedang. Kondisi yang demikian mendorong peneliti untuk mengadakan inovasi dalam kegiatan pembelajaran dengan mencoba melaksanakan kegiatan pembelajaran melalui penggunaan media yang diharapkan dapat menjadi strategi untuk menarik minat siswa dalam belajar.

Kemampuan memahami dan mengerti dinamika penduduk siswa kelas VIII D SMP Pangudi Luhur Bintang Laut Surakarta masih rendah. Hasil penelitian yang dilakukan peneliti menunjukkan bahwa dari 39 siswa, sebanyak 18 siswa hasil belajarnya masih rendah. Ada 18 siswa yang mendapatkan nilai di bawah KKM. Hasil belajar siswa kelas VIII D ini masih rendah karena jumlah siswa jumlah siswa yang mencapai nilai di atas KKM yang ditetapkan masih sedikit. KKM pada mata pelajaran IPS kelas VIII SMP Pangudi Luhur Bintang Laut Surakarta Tahun Pembelajaran 2017 - 2018 yaitu 75. Berdasarkan hasil pengamatan yang telah diuraikan maka pada kelas VIII D perlu adanya tindakan yang bervariatif sehingga perolehan hasil belajar meningkat. Maka peneliti akan menggunakan model pembelajaran kooperatif sistem Student Teams Achievement Division (STAD) agar pencapaian hasil belajar sesuai dengan KKM. Model pembelajaran kooperatif tipe STAD salah satu model pembelajaran yang tepat untuk meningkatkan aktifitas belajar siswa karena dengan model pembelajaran ini siswa mempunyai motivasi tinggi untuk meningkatkan kinerja kerja kelompok, bertanggungjawab, meningkatkan kinerja individu sehingga hasil belajar akan meningkat.

\section{B. Hasil Siklus I}

\section{Perencanaan Tindakan}

a. Menyusun langkah-langkah penelitian. Peneliti mengajak salah satu guru IPS yang bertugas sebagai observer.

b. Menentukan materi yang akan dijadikan standar kompetensi sebagai bahan penelitian. Kompetensi dasar yang dijadikan bahan penelitian adalah "Mengidentifikasi permasalahan kependudukan dan upaya penanggulangannya"

c. Menyusun RPP siklus I

d. Menyusun pre-tes dan pos-tes

e. Menyusun Lembar Kerja yang akan diselesaikan oleh tiap kelompok.

f. Membuat format observasi untuk kegiatan guru dan lembar blangko observer yang dipergunakan untuk mengamati kegiatan siswa selama proses belajar mengajar menggunakan tipe STAD.

\section{Pelaksanaan Tindakan}

a. Pelaksanaan tindakan pada siklus I dilaksanakan dengan alokasi waktu 2 jam pelajaran yaitu tanggal 25 Agustus 2017.

b. Pada siklus I kompetensi dasar yang disampaikan adalah permasalahan kependudukan di Indonesia, dampak, dan upaya mengatasinya.

c. Membagi kelompok masing-masing terdiri atas 4 siswa yang heterogen dari tingkat kemampuan tinggi hingga rendah dan jenis kelamin. 
d. Langkah-langkah pembelajaran dengan model pembelajaran kooperatif tipe STAD sebagai berikut:

1) Guru mengadakan presensi terhadap kehadiran siswa. Kemudian dilanjutkan pretes.

2) Guru menanyakan apa yang dimaksud dengan dinamika penduduk dan contohnya dalam kehidupan sehari-hari.

3) Guru memberi motivasi kepada siswa dengan cara menjelaskan tentang pentingnya materi ini dalam kehidupan sehari-hari.

4) Guru menjelaskan materi dinamika penduduk.

5) Guru menyuruh siswa agar duduk dalam kelompok masing-masing yang telah ditentukan sebelumnya.

6) Guru membagikan lembar kerja dan siswa mengerjakan soal secara berkelompok. Guru bertindak sebagai fasilitator membimbing dan membantu siswa yang mengalami kesulitan.

7) Guru meminta siswa agar saling membantu satu sama lain.

8) Guru meminta salah satu wakil dari kelompok untuk mempresentasikan hasil pekerjaannya.

9) Guru memberikan penguatan dan bersama siswa menyimpulkan materi.

10) Guru memberikan penghargaan pada kelompok yang bisa menjawab dengan benar.

\section{Observasi}

11) Guru memberikan pos- tes.

Observasi dilakukan oleh peneliti dan rekan serumpun sebagai observer. Hasil pengamatan didapat bahwa dalam melaksanakan pembelajaran dengan model pembelajaran kooperatif tipe STAD, guru telah menerapkannya sesuai dengan RPP. Berdasarkan hasil pengamatan observer ditulis dalam blangko observasi.

Data hasil belajar siswa siklus I adalah membahas permasalahan kependudukan di Indonesia, dampak, dan upaya mengatasinya. Dari data di atas, dapat dilihat bahwa pada post-tes nilai rata-rata siswa adalah 65,35. Dari 39 siswa yang mengikuti post-tes evaluasi terdapat 20 siswa yang tuntas belajar, persentase ketuntasan klasikal 55,6 \%. Nilai masih kurang dari ketuntasan belajar secara klasikal. Hal ini menunjukkan bahwa prestasi belajar siswa belum mencapai target dari prestasi belajar yang diinginkan yaitu ketuntasan belajar $75 \%$ meskipun rata-rata nilainya meningkat

\section{Refleksi}

Memperhatikan data pada tabel tersebut, maka kekurangan yang terdapat pada siklus I adalah:

a. Komunikasi dua arah antara guru dan siswa masih kurang.

b. Komunikasi kerja sama siswa dalam kelompok nampak kurang. Demikian juga siswa yang berkemampuan rendah enggan bertanya pada temannya yang lebih pandai.

c. Guru kurang banyak mendampingi siswa dalam berdiskusi.

d. Guru kurang bisa mengatur waktu, sehingga waktu untuk mengerjakan tidak cukup.

e. Guru kurang memotivasi siswa dalam membangkitkan minat pada awal pelajaran. adalah:

Memperhatikan kekurangan di atas, maka rencana perbaikan yang akan dilakukan pada siklus II

a. Guru mengajukan beberapa pertanyaan dan memberikan kesempatan kepada siswa untuk bertanya, sehingga komunikasi antara guru dan siswa tercipta.

b. Guru menentukan tutor sebaya untuk tiap-tiap kelompok agar mau membantu atau mengajari temannya yang belum bisa. Guru menekankan kepada siswa bahwa kelompok yang dikatakan berhasil apabila tiap anggota kelompoknya mengerti atau bisa menjawab pertanyaan yang diberikan. 
c. Guru lebih aktif memberikan bimbingan kepada tiap kelompok dengan terus mendekati tiap-tiap kelompok selama berdiskusi.

d. Guru mengatur kembali alokasi waktu pengerjaan Lembar Kerja serta menentukan jumlah soal sesuai dengan waktu yang tersedia.

e. Guru memberikan motivasi kepada siswa untuk membangkitkan minat pada pelajaran yaitu dengan memberikan gambaran tentang kegunaan materi yang sedang dipelajari dalam kehidupan sehari-hari.

\section{Hasil Siklus II}

\section{Perencanaan Tindakan}

a. Menyusun langkah-langkah penelitian. Peneliti mengajak salah satu guru IPS yang bertugas sebagai observer.

b. Menentukan materi yang akan dijadikan standar kompetensi sebagai bahan penelitian. Kompetensi dasar yang dijadikan bahan penelitian adalah "Mengidentifikasi permasalahan kependudukan dan upaya penanggulangannya"

c. Menyusun RPP siklus II

d. Menyusun pre tes dan pos tes

e. Menyusun Lembar Kerja yang akan diselesaikan oleh tiap kelompok.

f. Membuat format observasi untuk kegiatan guru dan lembar blangko observer yang dipergunakan untuk mengamati kegiatan siswa selama proses belajar mengajar menggunakan tipe STAD.

\section{Pelaksanaan Tindakan}

a. Pelaksanaan tindakan pada siklus II dilaksanakan dengan alokasi waktu 2 jam pelajaran yaitu tanggal 1 September 2017.

b. Pada siklus II kompetensi dasar yang disampaikan adalah Macam-macam pertumbuhan penduduk dan faktor-faktor yang mempengaruhinya.

c. Membagi kelompok masing-masing terdiri atas 4 siswa yang heterogen dari tingkat kemampuan tinggi hingga rendah dan jenis kelamin.

d. Langkah-langkah pembelajaran dengan model pembelajaran kooperatif tipe STAD sebagai berikut:

1) Guru mengadakan presensi terhadap kehadiran siswa. Kemudian dilanjutkan pre tes.

2) Guru menanyakan apa yang dimaksud dengan pertumbuhan penduduk dan contohnya dalam kehidupan sehari-hari.

3) Guru memberi motivasi kepada siswa dengan cara menjelaskan tentang pentingnya materi ini dalam kehidupan sehari-hari.

4) Guru menjelaskan materi pertumbuhan penduduk.

5) Guru menyuruh siswa agar duduk dalam kelompok masing-masing yang telah ditentukan sebelumnya.

6) Guru membagikan lembar kerja dan siswa mengerjakan soal secara berkelompok. Guru bertindak sebagai fasilitator membimbing dan membantu siswa yang mengalami kesulitan.

7) Guru meminta siswa agar saling membantu satu sama lain.

8) Guru meminta salah satu wakil dari kelompok untuk mempresentasikan hasil pekerjaannya.

9) Guru memberikan penguatan dan bersama siswa menyimpulkan materi.

10) Guru memberikan penghargaan pada kelompok yang bisa menjawab dengan benar.

11) Guru memberikan pos tes.

\section{Observasi}

Observasi dilakukan untuk mengetahui sejauh mana keterlaksanaannya pembelajaran dengan model pembelajaran kooperatif tipe STAD. Observasi dilakukan oleh peneliti dan rekan 
serumpun sebagai observer. Pada saat diskusi kelompok berlangsung, jika salah satu anggota kelompok bisa memahami dan menemukan jawabannya, maka dia akan membantu yang lain agar bisa memahami dan mengerjakannya juga. Hasil pengamatan didapat bahwa dalam melaksanakan pembelajaran dengan model pembelajaran kooperatif tipe STAD, guru telah menerapkannya sesuai dengan RPP. Berdasarkan hasil pengamatan observer ditulis dalam blangko observasi.

Data hasil belajar siswa siklus II adalah membahas permasalahan kependudukan di Indonesia, dampak, dan upaya mengatasinya. Dapat dilihat bahwa pada post- tes nilai rata-rata siswa adalah 85,53 . Dari 39 siswa yang mengikuti post-tes evaluasi terdapat 30 siswa yang tuntas belajar, persentase ketuntasan klasikal adalah $90 \%$. Nilai sudah memenuhi syarat minimal ketuntasan belajar secara klasikal. Hal ini menunjukkan bahwa hasil belajar siswa sudah mencapai target dari hasil belajar yang diinginkan yaitu ketuntasan belajar klasikal yang diatas $75 \%$.

\section{Refleksi}

Refleksi dilakukan oleh peneliti dengan rekan guru satu rumpun sebagai observer setelah pelaksanaan siklus II berakhir. Dari hasil refleksi menunjukkan bahwa pelaksanaan pembelajaran siklus II relative lebih baik dari pada pembelajaran siklus I. Post tes di siklus II bertujuan untuk mengukur peningkatan hasil belajar dalam pembelajaran IPS dengan model pembelajaran kooperatif tipe STAD. Pada post tes di siklus II terlihat bahwa sebagian besar siswa telah menjawab dengan memberikan langkah-langkah yang benar dan perhitungan yang tepat serta lengkap.

Berdasarkan data di atas diketahui bahwa terdapat peningkatan yang signifikan dari hasil belajar siswa yang kurang pada siklus I sudah dapat ditingkatkan pada siklus II, dengan demikian ini menunjukkan bahwa tujuan yang diharapkan yaitu meningkatkan hasil belajar siswa tercapai. Dari tindakan siklus II ternyata target yang ditetapkan oleh kurikulum sudah tercapai. Dengan demikian, maka pada siklus berikutnya dapat dihentikan karena telah diperoleh informasi-informasi yang cukup untuk mengambil beberapa keputusan sehubungan dengan target penelitian ini. Walaupun demikian masih ada beberapa siswa yang masih di bawah target, maka perlu mendapat perhatian khusus agar mendapat hasil yang lebih baik.

\section{Pembahasan}

Penelitian ini dilakukan sesuai dengan prosedur penelitian tindakan kelas (PTK) yang diawali pada perencanaan, pelaksanaan tindakan, observasi sampai refleksi. Berdasarkan analisis data pada post tes pelaksanaan pada siklus I menunjukkan bahwa nilai rata-rata kelas sebesar 65,35 dan persentase ketuntasan klasikal sebesar $50 \%$. Karena ketuntasan belajar pada siklus I belum mencapai target minimal, maka pelaksanaan tindakan dilanjutkan ke siklus II dengan melakukan perbaikan-perbaikan dan penyempurnaan kekurangan-kekurangan pembelajaran kooperatif STAD pada siklus I. Setelah melakukan perbaikan dalam proses pembelajaran, dari hasil analisa pada siklus II hasil belajar diperoleh nilai rata-rata kelas sebesar 85,53 dan persentase ketuntasan klasikal sebesar $90 \%$.

Dari data hasil post tes siklus I dan siklus II ditampilkan dalam bentuk tabel diperoleh data sebagai beikut:

Tabel 1. Hasil belajar pada post tes siklus I dan siklus II

\begin{tabular}{|c|c|c|}
\hline & Rata-rata post tes & Ketuntasan klasikal hasil post tes \\
\hline Siklus I & 65,35 & $55,6 \%$. \\
\hline Siklus II & 85.53 & $90.0 \%$ \\
\hline
\end{tabular}




\section{Hasil Uji Hipotesis}

Dari hasil yang diperoleh dalam model pembelajaran kooperatif tipe STAD dapat dilihat bahwa pembelajaran ini dapat meningkatkan hasil belajar siswa. Karena dalam model pembelajaran kooperatif siswa dapat saling membantu memahami pembelajaran dan memperbaiki jawaban teman serta kegiatan lainnya dengan mencapai tujuan belajar bersama. Hal ini sesuai dengan pendapat Suradi (2003) yang menyebutkan bahwa "Pembelajaran kooperatif telah diyakini menjadi salah satu alternatif dalam perbaikan kualitas pembelajaran IPS. Model ini lebih banyak melibatkan siswa dan menggalakkan siswa belajar bersama-sama dalam kelompok kecil dengan kemampuan yang heterogen. Dengan demikian interaksi personal siswa dalam pembelajaran IPS secara kooperatif menjadi hal yang penting untuk meningkatkan prestasi akademik, penerimaan keberagaman dan pengembangan ketrampilan sosial.

Berdasarkan tabel di atas, setelah diberi tindakan tampak adanya peningkatan hasil belajar dari siklus I dengan siklus II. Peningkatan hasil penguasaan materi dinamika penduduk ini dapat dilihat persentase ketuntasan yang dicapai. Pada pembelajaran kooperatif tipe STAD memungkinkan diantara siswa-siswa akan mendukung dan membantu.

\section{KESIMPULAN}

Berdasarkan rumusan masalah, hasil penelitian, dan pembahasannya yang terdapat pada bab IV, maka penelitian ini yang dilaksanakan di kelas VIII D SMP Pangudi Luhur Bintang Laut Surakarta dapat disimpulkan bahwa model pembelajaran STAD dapat dipakai dalam proses pembelajran pada materi Dinamika Penduduk. Melalui pembelajaran dengan menggunakan model pembelajaran kooperatif tipe Student Teams Achievement Devisions (STAD) dapat meningkatkan hasil belajar siswa. Peningkatan hasil belajar siswa terlihat dari ketuntasan klasikal, pada pra siklus $55,6 \%$. siklus I ketuntasannya tetap $55,6 \%$ namun rata-rata nilainya meningkat sedangkan siklus II ketuntasannya $90 \%$.

\section{SARAN}

Berdasarkan uraian pada bagian kesimpulan, maka peneliti mengemukakan saran yang bertujuan untuk perbaikan pembelajaran IPS selanjutnya. Sebaiknya guru mempunyai pengetahuan dan ketrampilan serta menerapkan model pembelajaran di sekolah. Dengan menerapkan model pembelajaran STAD sebagai variasi dalam pembelajaran sehingga dapat menghindari kejenuhan. Sebaiknya model pembelajaran STAD ini dapat dikembangkan agar pembelajaran di kelas lebih menyenangkan dan mengaktifkan peran siswa sebagai pembelajar. Hendaknya guru IPS mengikuti perkembangan pembelajaran IPS dengan lebih aktif dan kreatif, terlibat dalam kegiatan guru IPS, membaca buku tentang metode-metode pembelajaran, membaca jurnal-jurnal penelitian pendidikan IPS dan lain-lain. Dengan demikian guru mempunyai wawasan yang luas tentang pendidikan IPS, sehingga guru mampu mengajar guru mampu menggunakan berbagai metode pembelajaran. Hendaknya guru dalam proses pembelajaran banyak melibatkan siswa, guru sebagai fasilitator dan motivator, guru tidak mendominasi seluruh proses pembelajaran. Dalam memilih model pembelajaran hendaknya guru memperhatikan faktor-faktor yang mempengaruhi proses dan hasil belajar siswa.

\section{DAFTAR PUSTAKA}

Ali, M. \& Asrori, M. (2008). Psikologi Remaja Perkembangan. Peserta Didik. Jakarta: PT. Bumi Aksara. Hamalik, O. (2005). Kurikulum dan Pembelajaran. Jakarta: Bumi Aksara 
Hutabalian, E., \& Gunansyah, G. (2013). Upaya Meningkatkan Hasil Belajar Siswa pada Mata Pelajaran IImu Pengetahuan Sosial Melalui Penerapan Model Kooperatif Tipe STAD di Kelas IV SDN Kertajaya IV Surabaya. Jurnal Penelitian Pendidikan Guru Sekolah Dasar, 1 (2), 1-6

Purwati, C., Akhyar, M., \& Fadhilah, S.S. (2017). Peningkatan Motivasi dan Hasil Belajar Melalui Implementasi Model STAD Pada Mata Pelajaran PKn Kelas IV SD 5 Bae Kabupaten Kudus Tahun Ajaran 2014/2015. Teknodika, 15 (1), 9-15

Rochmatin \& Gunansyah, G. (2014). Penerapan Model Pembelajaran Kooperatif Tipe STAD Meningkatkan Hasil Belajar Siswa dalam Pembelajaran IPS Kelas IV. Jurnal Penelitian Pendidikan Guru Sekolah Dasar, 2(3), 1-8

Slameto. (2003). Belajar dan Faktor-faktor yang Mempengaruhinya. Jakarta: Rineka Cipta.

Sudjana, N. (2007). Dasar-dasar Proses Belajar Mengajar. Bandung: Sinar Baru Algensindo

Suparno, P. (2005). Miskonsepsi dan Perubahan Kosep dalam Pendidikan Fisika. Jakarta: Grasindo. 